\title{
An overview of Cladoceran studies conducted in mine water impacted lakes
}

\author{
Jaakko Johannes Leppänen
}

Received: 16 May 2018/Accepted: 16 August 2018/Published online: 23 August 2018

(C) The Author(s) 2018

\begin{abstract}
Mine-fed waters have been rigorously studied, but most of the ecological research on mine water has been conducted in riverine systems. Lakes, however, are known to recover from pollution more slowly than riverine systems and, thus, the impacts of mine water on lakes are equally interesting. One of the most important biological components in lakes are the Cladocera, an order of crustacean zooplankton. Cladocerans are regarded as excellent indicators of environmental change and, for example, genus Daphnia is one of the most used test organisms in ecotoxicology. While in vitro tests regarding pollutants and cladocerans have been reviewed multiple times, the literature regarding the community level responses to mine pollution in natural settings is still to be better explored. The main aim of this paper is to screen and compile the current literature related to cladoceran communities and mine-induced water pollution. In addition, the applicability of cladocerans as a bioindicators group in mine water studies will be explored. This review shows that cladocerans have been studied in many cases of mining related pollution and most of the research has been conducted in North America, central Europe and Brazil. Acidity, turbidity and metals pollution are nearly equally important in shaping cladoceran communities in mining impacted lakes. The most tolerant taxa to mining pollution are Bosmina spp. and Chydorus sphaericus. The group clearly has potential as community level bioindicator/biomonitor in mining pollution studies, but challenges remain. Namely, the lack of data regarding the most sensitive taxa is a major problem when indicator value of any single species is assessed.
\end{abstract}

Keywords Mining $\cdot$ Pollution $\cdot$ AMD $\cdot$ Tailings $\cdot$ Zooplankton $\cdot$ Water flea

\section{Introduction}

Although the reservoirs of high grade deposits are continuously decreasing (Watling 2015), the total mineral production has actually doubled in the past 30 years (Reichl et al. 2016). The increased exploitation of low grade ores results in higher amount of mine waste (Hudson-Edwards and Dold 2015) and, in many cases, subsequently larger quantities of potentially harmful mine water. Thus, there is a growing need for monitoring tools, which are suitable for reliable assessment of ecological conditions in mine water impacted lakes. Potentially harmful mine waters are known to exhibit a wide range of acid to alkaline conditions ( $\mathrm{pH}-2.5$ to 11.7) and based on chemical composition, mine water can be characterized in a plethora of ways (e.g., saline, radioactive, corrosive or toxic; Nordstrom 2011). However, the environmental impacts of mine water are even

\footnotetext{
J. J. Leppänen $(\bowtie)$

Environmental Change Research Unit (ECRU) and Helsinki Institute of Sustainability Science, Faculty of Biological and Environmental Sciences, University of Helsinki, P.O. Box 65, 00014 Helsinki, Finland

e-mail: jaakko.leppanen@helsinki.fi
} 
more diverse. This is mainly due, but not limited to, the variability in species sensitivity to harmful substances and to the physical and chemical characteristics of the receiving environment (e.g., Kozlova et al. 2008). Environmental impacts of mine waters on lakes have been acknowledged for centuries (e.g., Wolkersdorfer and Bowell 2005) but because the effluent is usually released into lotic (flowing) waters, this has gained most of the attention in research. While riverine systems are known to recover fast when pollution stops (Yount and Niemi 1990), lakes tend to recover slowly because of longer residence times. In some cases, the recovery may be further delayed by sedimentary contamination (Rogalski 2015) and mine water induced meromixis, especially in pit lakes (e.g., Schultze et al. 2017).

Bioindicators/biomonitors are attractive tools for pollution researchers. The idea is that the biota is the best indicator of ecological changes as it provides the data concerning the actual biological impacts (Zhou et al. 2008). In mine water studies, the popular bioindicator species are riverine insect larvae (Cain et al. 1992; Salmelin et al. 2017) and acidophilic algae (e.g., Valente and Gomes 2007). In lakes, one of the most promising indicator groups for mine pollution is the Cladocera; an order of microscopic aquatic Crustacea, which are excellent indicators of environmental change (Jeppesen et al. 2011). Cladocera colonize almost every type of fresh waters and they are usually highly abundant. The group is of vital importance to the wellbeing of aquatic systems due to their position in food webs. Cladocerans transfer energy from primary producers towards higher trophic levels, such as juvenile fish (Sterner 2009).

There is a large body of knowledge regarding the effects of harmful substances on cladocerans from in vitro testing (Sarma and Nandini 2006; Suhett et al. 2015). In fact, the applicability of cladocerans to mining contamination assessment is further highlighted in Canadian metal mining effluent regulations (Canadian Government 2002), which include Daphnia magna monitoring tests to be conducted on a monthly basis as a part of mine water monitoring programs. Despite the obvious advantages of in vitro studies (standardized protocols, low cost), the comparability of in vitro tests with changes in situ is not well understood. Whereas the results of ecotoxicological laboratory tests using Cladocera have been reviewed several times (e.g., Sarma and Nandini 2006; Persoone et al. 2009; Bownik 2017), the impact of mine water on natural cladoceran communities has not been reviewed.

This contribution focuses on the effects of mine-impacted waters on lentic cladoceran communities and populations in an attempt to compile relevant studies. The second goal is to assess the suitability of cladocerans as a community-level bioindicator tool in studies of mine-related lake pollution.

Scientific bibliographic databases (BioOne, EBSCO, Web of Science, Google Scholar) were used to find the research literature considering the impacts of mine water release or tailings dumping on cladoceran communities (search terms cladocera AND mining, cladocera AND AMD, cladocera and mine water, cladocera AND tailings, cladocera AND acid mine drainage). Because the mine water impact is difficult to differentiate from other stressor sources in the catchment and airborne pollution, only the cases where point sources are clearly identified are reviewed here. In addition, all in vitro tests are omitted from this review whereas mining pit lakes and man-made reservoirs are included and are discussed together with natural waterbodies.

\section{Mine water pollution as a multi-stressor problem}

The mine waters only rarely contain a singular component, which can be deemed as a single factor which induces ecological impacts. Mine waters can simultaneously exhibit high metals concentrations, elevated salinity and high concentrations of solids and these different constituents and characteristics affect each other. For example, $\mathrm{pH}$ and redox potential can be regarded as the most important parameters which control the solubility, and thus the availability, of trace metals to biota. The processes involved are precipitation, adsorption, oxido-reduction and complexation (Bourg and Loch 1995). Toxicity tests for Cladocera are being designed to discriminate the toxicity due to metals and low pH (Lopes et al. 1999) and the bioavailability of some metals can be assessed using biotic ligand models (BLM), where local water characteristics are taken into account (Niyogi and Wood 2004). However, all BLM tools have pronounced applicability ranges for many parameters (e.g., pH, DOC, Ca, Mg, Na, SO; Vink and Verschoor 2010). Further, in some cases, mine effluent affects these parameters and subsequently hampers the analysis of the mine water impact. Thus, the issue is complicated by the synergic or antagonistic effects of mine water components (e.g., metals; Smirnov 2017). In addition, the varying effects of contaminants also depend on the route of exposure (e.g., dietary 
exposure, direct exposure; Sofyan et al. 2009). Even though the environmental impacts of elevated salinity and dissolved solids have not been studied as intensively as acid drainage in mine water research, they constitute an important and potentially critical component in mine water toxicity. Salinity (sulfate, sodium, calcium) induces osmotic stress to fresh water biota and may turn the water body meromictic (Molenda 2014). The meromixis is a result of the incomplete mixing of dense (saline) effluent and overlying freshwater which may lead to permanent anoxia in deep bottoms. The elevated concentrations of solids may contribute to habitat degradation due to diminished water clarity and elevated siltation. Further, elevated concentrations of suspended minerals (turbidity) are harmful to cladocerans (McCabe and O'Brien 1983; Cuker 1987; Hart 1987; Kirk and Gilbert 1990). In addition, the accompanying impacts (changes in water clarity, trophic status, acidification, predator community or food availability) may induce additional difficulties in mine pollution research. Due to the complex character of mine pollution, the most convenient way to present the current research is to organize the literature based on mined material rather than pollutant.

\section{Cladocera and metal mining}

Bauxite

Lake Batata, located in Amazonia, Brazil has been impacted by bauxite mining tailings, which are high in very fine solid particles and in aluminum and iron oxides. The tailings were dumped into the lake for 10 years (18 million $\mathrm{m}^{3}$ /year), which has resulted in greater variation in cladoceran density and brood size when compared to a non-impacted area (Bozelli 1996). In addition, cladocerans collected from impacted site showed smaller body sizes but higher weights which were explained by ingestion of tailings material (Maia-Barbosa and Bozelli 2005). Moreover, a 7-year study indicated that the highest impact of tailings was detected during the low water period and that Diaphanosoma birgei and Bosmina hagmanni dominated during the turbid phases (Garrido et al. 2003) suggesting high tolerance to turbidity, whereas Moina minuta was negatively impacted by high turbidity. Thus, $M$. minuta would be interesting species if the impacts of suspended solids pollution were to be assessed in the future studies in the region. The impact of seasonal water level fluctuations, which also result in changes in turbidity, is characteristic in these studies. Therefore, it is difficult to postulate the most important stressor, because other season-related environmental conditions (e.g., temperature, food availability) probably vary simultaneously with the turbidity. The ingestion of tailings particles by cladocerans is potentially highly important component when ecological impacts of tailings are considered because species exhibit morphological differences of feeding apparatus, which has been suggested to contribute to the ability of selective (e.g., ability to reject inedible particles) feeding (Smirnov 2017).

Copper and gold

Doig et al. (2015) investigated the impact of acid and metal-contaminated effluent originating from $\mathrm{Cu}-\mathrm{Zn}$ mine on Bosmina longirostris abundance in a small boreal lake in Manitoba, Canada. The authors detected severe reduction in community size, which was related both to acidity and zinc contamination. Similarly, Kerfoot et al. (1999) detected a pronounced decline in Bosmina production in oligo-mesotrophic (pH 6.5-9.1) lake, Keweenaw Waterway in Michigan USA, due to copper pollution (maximum copper sediment flux $579 \mu \mathrm{g} / \mathrm{cm}^{2} / \mathrm{yr}$ ) inflicted by historical (1848-1920) mining activities. Different cladoceran species exhibit high variation in copper tolerance (12-fold differences in copper tolerance have been reported; Bossuyt and Janssen 2005). B. longirostris is regarded as more sensitive to copper pollution than many other cladoceran species (Koivisto et al. 1992; Koivisto and Ketola 1995; Bossuyt and Janssen 2005) which may explain the above mentioned deleterious impact. Leppänen et al. (2017b) reported decreased diversity and species richness in Lake Kirkkojärvi, southern Finland, which has been affected by increased input of mineral matter and minor metal pollution, originating from tailings impoundment of $\mathrm{Au}-\mathrm{Cu}$ mine around 1960-1970, but the lake has never acidified due to rapid dilution. The most pronounced impact was detected during the input of fine mineral tailings. Polyphemus pediculus, Eubosmina coregoni, Daphnia sp., Alonella excisa, A. quandranqularis, Alonopsis elongata and Disparalona rostrata were negatively affected. In addition, the cladoceran community in the shallow embayment of the same lake is unharmed by low volume but continuous high- $\mathrm{Cu}$ 
low $\mathrm{pH}$ effluent (since 1970s) because the pollution is most intense during early spring, when the cladoceran communities are mostly absent (Leppänen et al. 2017a). The lucky mismatch is further reflected in increased abundance of $B$. longirostris, which is especially sensitive to copper pollution but thrives in eutrophicated systems, such as Lake Kirkkojärvi.

Iron

Holopainen et al. (2008) reported potassium to be the most harmful element to the planktonic ecosystem in Russian lakes impacted by alkaline mine water released from iron mine. Species number was low $(<7)$ and the impacted lakes ( $\mathrm{pH} 7.7-8.0$, EC 49-391 $\mu \mathrm{S} / \mathrm{cm})$ were dominated by B. longirostris whereas in the nonimpacted reference lake ( $\mathrm{pH} 6.7-6.8$, EC $24-28 \mu \mathrm{S} / \mathrm{cm})$ the dominating species was Daphnia cristata. The elevated conductivity of the impacted lake may explain the dominance of $B$. longirostris, a species known to inhabit high conductivity waters (Zawisza et al. 2016). In contrast, Bradbury and Megarad (1972) found that the cladoceran community in Shagawa Lake (Minnesota, US) shifted from a B. longirostris dominated system towards higher abundance of Chydorus sphaericus due to onset of anthropogenic eutrophication and the effluent (hematite rich effluent) originating from iron mine. The authors suggest that the reason for species shift is related to cyanobacterial blooms, but still, this trend is very interesting, because both species are regarded to prefer eutrophicated waters (e.g., Nevalainen and Luoto 2013) and to tolerate cyanobacterial blooms (Tõnno et al. 2016). However, the species differ in their tolerance on heavy metals (Bossuyt and Janssen 2005) and solids pollution (elevated conductivity; Zawisza et al. 2016). However, no metals concentrations data are available from Lake Shagawa. Changes in species assemblages are also reflected in species richness as Winegardner et al. (2017) reported the pronounced decrease in cladoceran species richness to correlate with iron mining derived metal pollution in Quebec, Canada. In species level, C. sphaericus was able to remain relatively unharmed by pollution. Moreira et al. (2016) compared zooplankton communities in two artificial lakes, in Mata Porcos, Brazil, which receive mining effluent from two different mines. The cladoceran community in the lake which was affected by kaolinite mining (pH 6.8-0.7.1, EC 12.1-16.2 $\mu \mathrm{S} / \mathrm{cm}$, barium $24.0-53.3 \mu \mathrm{g} / \mathrm{L}$, manganese $66.3-248.7 \mu \mathrm{g} / \mathrm{L}$, zinc $0.0-12.5 \mu \mathrm{g} / \mathrm{L}$ ) was dominated by $B$. longirostris, whereas the cladoceran assemblage was more diverse (Eubosmina tubicen, Bosminopsis deitersis, Alonella clathratula, Ilyocryptus spinifer) in the lake which was affected by iron mine effluent ( $\mathrm{pH} 5.4-6.4$, EC 2.9-18.1 $\mu \mathrm{S} / \mathrm{cm}$, barium 4.2-6.9 $\mu \mathrm{g} / \mathrm{L}$, manganese $12.4-109.7 \mu \mathrm{g} / \mathrm{L}$, zinc $4.2-68.9 \mu \mathrm{g} / \mathrm{L})$. Here, despite some differences in water chemistry between two lakes, the reported concentrations are low in terms of toxicity (ECOTOX 2017) and no clear reason behind the community differences can be drawn from the water chemistry alone.

Nickel, tin and zinc

Saline and metal-contaminated mine water originating from Talvivaara Terrafame $\mathrm{Ni}-\mathrm{Zn}-\mathrm{Cu}$ mine (central Finland) resulted in nearly total disappearance of Daphnia cucullata and clear dominance of B. longirostris and turned the receiving lakes meromictic with maximum concentration of $1200 \mathrm{mg} / \mathrm{L}$ of sulfate in surface water. Whereas the metals concentration in lake water has remained relatively low, the salinity-induced stress and the stratification of the waterbody (and resulting physical changes in lake) probably contributed more to the community change (Leppänen et al. 2017c). The cladoceran production greatly diminished and clear changes in species composition were detected in Datun Lake, China, which was impacted by mineral tailings and elevated arsenic concentrations originating from tin mining. Particularly, Eubosmina longispina and Alona guttata/rectangula were adversely affected as the production declined over 80\% (Chen et al. 2016). Wilk-Woźniak et al. (2011) studied plankton communities in fishponds contaminated by heavy metal runoff from $\mathrm{Zn}-\mathrm{Pb}$ mine "Matylda" in south Poland and found an extremely poor cladoceran community. The maximum proportion of cladocerans among zooplankton was only 3\% (total density) and the only reported species was E.coregoni.

Uranium

Ferrari et al. (2009) reported Bosmina sp. as the only species in waste water of a uranium mine in Poços de Caldas Plateau region, Brazil, with elevated conductivity $(2415 \mu \mathrm{S} / \mathrm{cm}) \mathrm{pH}$ of 3.9 and high uranium 
concentration $(4.3 \mathrm{mg} / \mathrm{L})$. However, also the low impact reference lake was noted as being unsuitable for cladocerans as only 2 species (Diaphanosoma and Bosmina) were recorded. The reference lake is characterized by fluctuation in the water properties (e.g., $\mathrm{SO}_{4}{ }^{2-} 12.4-253.4 \mathrm{mg} / \mathrm{L}$, hardness $41.49-323.4 \mathrm{mg} / \mathrm{L}$ ) (Ferrari et al. 2017) which may explain the low cladoceran diversity. In addition, Bosmina -group species (Bosminopsis deitersi and Bosmina sp.) were detected to be the only cladoceran taxa in a newly formed acidic uranium pit lake in the same region with mean $\mathrm{pH} \mathrm{3.8,} \mathrm{electrical} \mathrm{conductivity} \mathrm{of} 2391 \mu \mathrm{S} / \mathrm{cm}$, sulfate concentration of $1413 \mathrm{mg} / \mathrm{L}$ and uranium concentration of $3 \mathrm{mg} / \mathrm{L}$ (Ferrari et al. 2015). Interestingly, Melville (1995) reported a clear shift (the loss of Bosmina) in the cladoceran community and pronounced dominance of Ceriodaphnia reticulata in a small boreal lake in Canada, which was affected by uranium mine effluent resulting in elevated concentrations of uranium $(0.54 \mathrm{mg} / \mathrm{L})$ and sulfate $(1140 \mathrm{mg} / \mathrm{L})$ in lake water. These pronounced differences in dominant species in high $\mathrm{U}$ and high sulfate lakes suggest that the reasons behind the cladoceran changes are complicated and in addition to water chemistry are probably also related to regional (e.g., climatic) variables.

\section{Cladocera and fuel minerals mining}

Black coal, lignite and oil sands

Canton and Ward (1981) reported extremely poor cladoceran community (sole species was B. longirostris $<1$ individual/L) in a coal mine pond (Pond 1) in NW Colorado USA, which had received mine water ( $\mathrm{pH} 7.4$, total dissolved solids (TDS) $3811 \mathrm{mg} / \mathrm{L}$, nitrate $16.34 \mathrm{mg} / \mathrm{L}$ ) for a decade. In the older pond (Pond 2), with lower contamination levels ( $\mathrm{pH} 7.4$, TDS $1770 \mathrm{mg} / \mathrm{L}$, nitrate $0.55 \mathrm{mg} / \mathrm{L}$ ), the cladoceran community covered more species (C. sphaericus, D. pulex, B. longirostris). The cladoceran community of the control site (Pond 4) (pH 7.6, TDS $547 \mathrm{mg} / \mathrm{L}$, nitrate $0.14 \mathrm{mg} / \mathrm{L}$ ) was devoid of $B$. longirostris and the dominating species was $C$. reticulata, followed by $D$. pulex, $C$. sphaericus and A. guttata. Whereas the extremely low cladoceran abundance in the most polluted pond (Pond 1) may result either from nitrate or solids pollution, the nitrate levels in other two ponds (Ponds 2 and 4) are well below safe levels (Camargo et al. 2005) suggesting impact due to solids pollution. Because many lignite deposits in central Europe are located in sulfide-rich areas, the abandoned mines once filled with water are prone to acidification and metal pollution (Miller et al. 1996). In Lusatia (eastern Germany) on its own, the number of acidic pit lakes exceeds 400 (Nixdorf et al. 1998). In central Germany lignite mining district, approximately $50 \%$ were earlier or currently are acidic (Schultze et al. 2010). Mining pit lakes are occasionally affected by varying dilution regimes or pollution gradients. For example, a strong pH gradient in mining pit lake Lake Senftenberger See (Germany) is reflected in cladoceran species richness along this gradient (Belyaeva and Deneke 2007) with C. sphaericus being the only species present along the whole $\mathrm{pH}$ range $(\mathrm{pH} 3-7)$. The $\mathrm{pH}$ tolerance of $C$. sphaericus was also demonstrated by Klapper and Schultze (1995) as they noticed C. sphaericus in lignite pit lakes in Germany at the $\mathrm{pH}$ of 2.9, whereas Daphnia was detected only in lakes with the pH of 6 or higher. In addition, Wollmann et al. (2000)reported $C$. sphaericus from acidic pit lakes Felix (pH 3.6) and L117 (pH 2.8) in Germany. Similarly, Sienkiewicz and Gasiorowski (2016) found that C. sphaericus was the only species present in a highly acidic mining lake (Lake TR-33, Poland) before neutralization and subsequent normalization of the cladoceran community. Moser and Weisse (2011) compared zooplankton communities between two meromictic mining lakes in Austria, one of which was neutralized 25 years ago whereas the other had remained acidic ( $\mathrm{pH}$ 2.6). The acidic lake was devoid of cladocerans, whereas Daphnia and Bosmina were recorded occasionally in the neutralized lake during the 2-year period. However, the characteristics of the neutralized lake varied interannually, resulting in fluctuation between $\mathrm{pH} 4.3$ and 8.0 probably hampering the successful establishment of a rich cladoceran community. The mining pollution impacts on cladocerans, even when pollutants are highly toxic, are not always so straightforward. Kurek et al. (2012) studied cladoceran community changes in six lakes in Alberta, Canada, that have been affected for decades by PAHs (polycyclic aromatic hydrocarbons) input originating from the oil sands mining. However, the major shifts in cladoceran communities occurred before the oil sands mining started and, thus, the effect of PAHs contamination is uncertain. 


\section{Cladocera and other mines}

Apatite

Vandysh (2004) concluded that the pollution induced by apatite-nepheline tailings and mine water since the 1930s induced a clear shift in cladoceran community in Belaya River watershed located on the Kola peninsula, NW Russia. The author suggested that the tailings-derived turbidity and also the eutrophication resulted in the disappearance of D. cristata, Holopedium gibberum, Leptodora kindti and Bythotrephes cedestromii. The most common species in polluted areas was Bosmina obtusirostris (syn. Bosmina (Eubosmina) coregoni). The loss of large sized species is particularly interesting as the large bodied species are valuable food items for fish but also more vulnerable to fish predation than small bodied taxa (Brooks and Dodson 1965), adding another component to the ecological changes in Belaya River watershed.

Basalt

El-Bassat and Taylor (2007) noted cladoceran species being extremely rare (B. longirostris, Pleuroxus sp. and Alona sp. were detected) in alkaline ( $\mathrm{pH} \mathrm{7.8-8.5),} \mathrm{saline} \mathrm{(EC} \mathrm{28,000} \mu \mathrm{S} / \mathrm{cm}$ ) and eutrophic Abp Zaabal Lake, which occupies a former basalt mine, in Cairo, Egypt. It must be noted, however, that Abp Zaabal Lake is highly impacted by waste water input unrelated to mining, which prevents any generalizations regarding the role of initial pit lake chemistry on cladoceran community.

Diamonds

The effluent (showing elevated concentrations of $\mathrm{Ca}^{2+}, \mathrm{K}^{+}, \mathrm{SO}_{4}{ }^{2-}, \mathrm{Na}^{+}, \mathrm{Mg}^{2+}, \mathrm{HCO}_{3}{ }^{-}$) originating from the Ekati mine, a diamond mine located in northern Canada, was reported to inflict distinct changes in cladoceran communities in the chain of lakes along the pollution gradient. The species, which usually dominates softwater low-Ca lakes in the region, Holopedium glacialis, was substituted by Daphnia longiremis and Daphnia middendorfiana due to elevated $\mathrm{pH}$ and $\mathrm{Ca}$ enrichment (Griffiths et al. 2018).

Gypsum

Alkaline (pH 7.6-0.7.9) gypsum mine pit lakes in Croatia, with very high concentrations of solids (TDS > $2000 \mathrm{mg} / \mathrm{L})$, calcium ( 1300-1400 mg/L) and sulfate ( 400-1300 mg/L) were dominated by Chydorus sp. and $C$. reticulata, whereas a non-gypsum karst lake ( $\mathrm{pH} 7.9, \mathrm{EC}<482 \mu \mathrm{S} / \mathrm{cm}$, calcium $240 \mathrm{mg} / \mathrm{L}$, sulfate $12.8 \mathrm{mg} / \mathrm{L}$ ) was dominated by $B$. longirostris and Ceriodaphnia quadrangula. The community difference was suggested to originate from the reduced feeding efficiency in gypsum lakes (Stankovic et al. 2011).

\section{Hematite}

Coard et al. (1983) detected the total, but relatively temporal loss of planktonic taxa and subsequent dominance of a chydorid species in a lake located in Cornwall, England, which was affected by hematite-clay input due to mining activities in the early twentieth century. The loss of planktonic taxa may be related to increased concentrations of solids and subsequently decreased feeding efficiency for planktonic filter feeder species (e.g., Arruda et al. 1983; Stankovic et al. 2011).

Sand

Sand and gravel extraction pit lakes in, e.g., Hungary (Vad et al. 2012) and Croatia (Stankovic and Ternjej 2009) harbor relatively rich and diverse cladoceran communities. In addition, one species (Macrothrix laticornis), seldom detected in Belgium in the early twentieth century, has been discovered to exploit newly dug sand pits and has thus been able to become relatively widespread (Dumont 1989). 
Sulfur

A pit lake, formed due to the abandonment of a sulfur mine in Tarnobrzeg (Poland) is characterized by slightly alkaline pH (7.2-8.6), elevated hardness (1000-2000 $\left.\mathrm{mg} \mathrm{CaCO}^{3}\right)$, and the lake is meromictic. Chaoborus flavicans, which is an efficient predator and may affect the cladoceran community (Jäger et al. 2011), was detected. The general cladoceran abundance was low and planktonic species D. cucullata and B. longirostris dominate the cladoceran community (Wilk-Woźniak and Zurek 2006). This particularly interesting case would deserve long-term monitoring study or paleolimnological study to examine the roles of meromixis, water chemistry and predation on cladoceran community structure.

\section{Cladocera in mine water research}

The available literature regarding the impacts of mine water on cladoceran communities in lake environments is still rather scarce. Moreover, only 11 of the reviewed studies included an adequate temporal dimension to allow the analysis of the community dynamics, which constitutes vital information regarding impact assessments or restoration planning. There seems to be few regional hotspots where cladoceran communities and mining pollution have been studied in natural waters (Table 1). This regional variation in cladoceran studies is probably related to the number of lakes in different regions. Most important stressors in reviewed papers were acidity, metals and salinity or solids. In most cases, species shifts or changes in productivity are reported. In addition to direct toxic impacts inflicted by high aquatic concentrations of harmful elements, also low concentrations of harmful elements (or changes in lake chemistry regarding non-toxic constituents) or other ecological changes may result in distinct impacts in cladoceran populations. The stress induced by exposure to elevated salinity has been reported to interfere with cladoceran reproduction (Elphick et al. 2011; Van Dam et al. 2014), whereas cladoceran growth is negatively affected by changes in food availability (mineral ingestion instead of edible particles; Maia-Barbosa and Bozelli 2005) and in food quality (e.g., increased abundance of cyanobacteria; Lundstedt and Brett 1991). Declining clutch sizes and inhibited growth are reflected in cladoceran productivity. The most sensitive taxa disappear first, which is reflected in diversity. Because cladocerans rely on sedimentary egg banks as temporal refugia to bypass seasonal or ecological "hardships" (e.g., winter or crowding), the sedimentary pollution may also have a pronounced impact on cladoceran communities (Rogalski 2015).

The most tolerant species regarding mine water impact belong to the Chydorus and Bosmina-groups. Namely, C. sphaericus is clearly able to thrive in acidic lakes, whereas Bosmina sp. does not exhibit special tolerance to any particular pollutant but seems to tolerate solids pollution relatively well. Comprehensive autecological analysis has not been published for either B. longirostris or C. sphaericus but according to (Błędzki and Rybak 2016) Chydorus cf. spahericus and Bosmina spp. are wide spread and abundant in many types of water bodies both in littoral and pelagial zone with high stress tolerance.

The applicability of cladocera as bioindicators/biomonitors

As defined by Markert et al. (2003), bioindicators are organisms (or, e.g., communities) that contain information on the quality of the environment, whereas biomonitors are organisms (or, e.g., communities) that contain information on the quantitative prospects of the environment. Thus, biomonitors are always bioindicators as well. In general, cladocerans fulfill many of the characteristics that are deemed important for any bioindicator organism. Namely, cladocerans are sensitive to pollution (Von Der Ohe and Liess 2004) and have short life cycles (Smirnov 2017), resulting in rapid responses to environmental stress. Recently, cladocerans have been used to study community level responses to environmental variables in many types of environments, e.g., dystrophic lakes in central Europe (Zawisza et al. 2016), subarctic lakes in Finland (Leppänen et al. 2016) and crater lakes in western Uganda (Rumes et al. 2011). The potential of cladocerans as a community level indicator tool in mining pollution studies is highlighted in the results of this review as the community shifts are clearly visible in most of the studies which span from pre- to post impact conditions. In addition, most of the results indicate distinct differences between impacted and reference sites. However, whether the overall conditions of an ecosystem can be determined by studying only one group of organisms is 


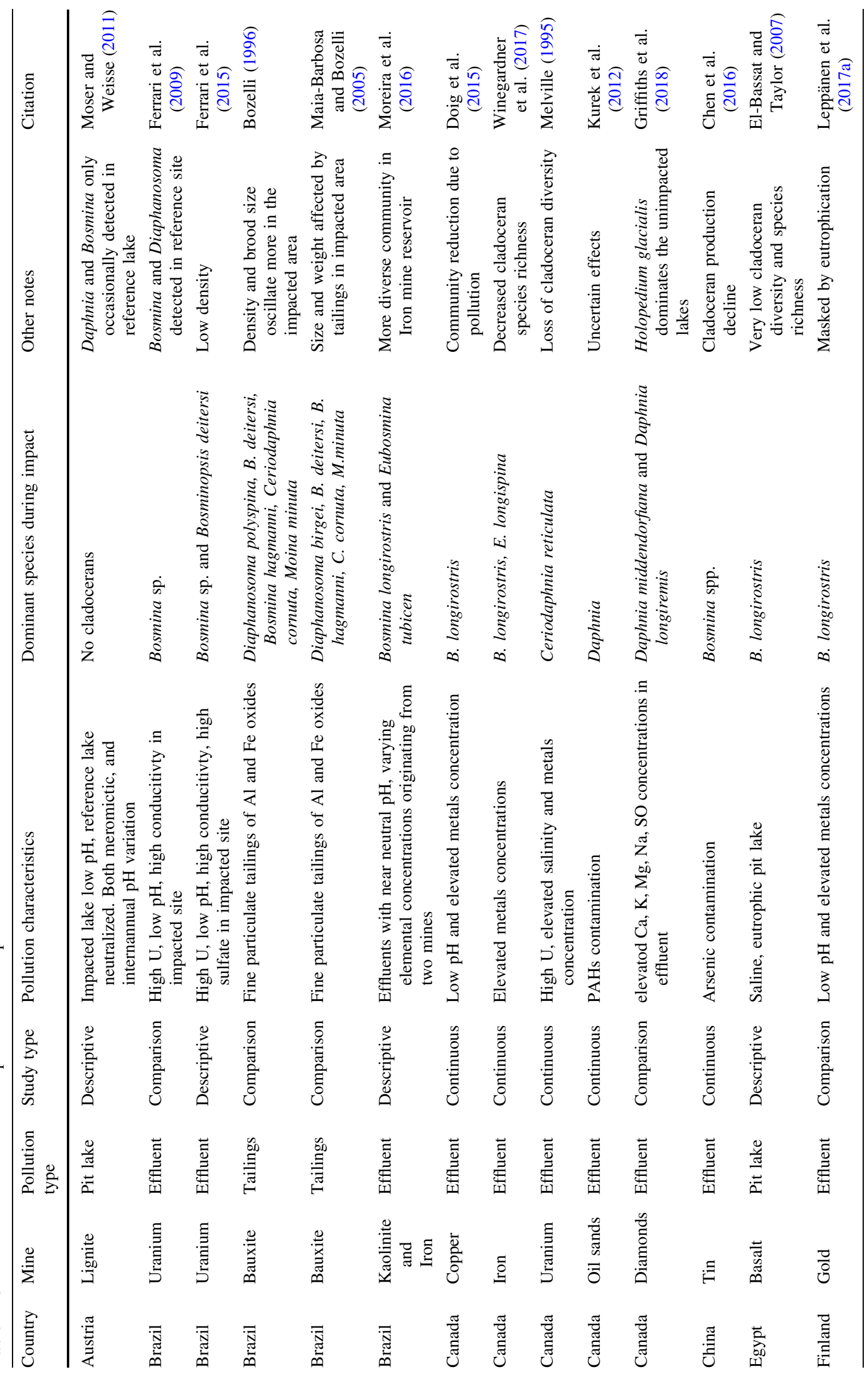

望 Springer 


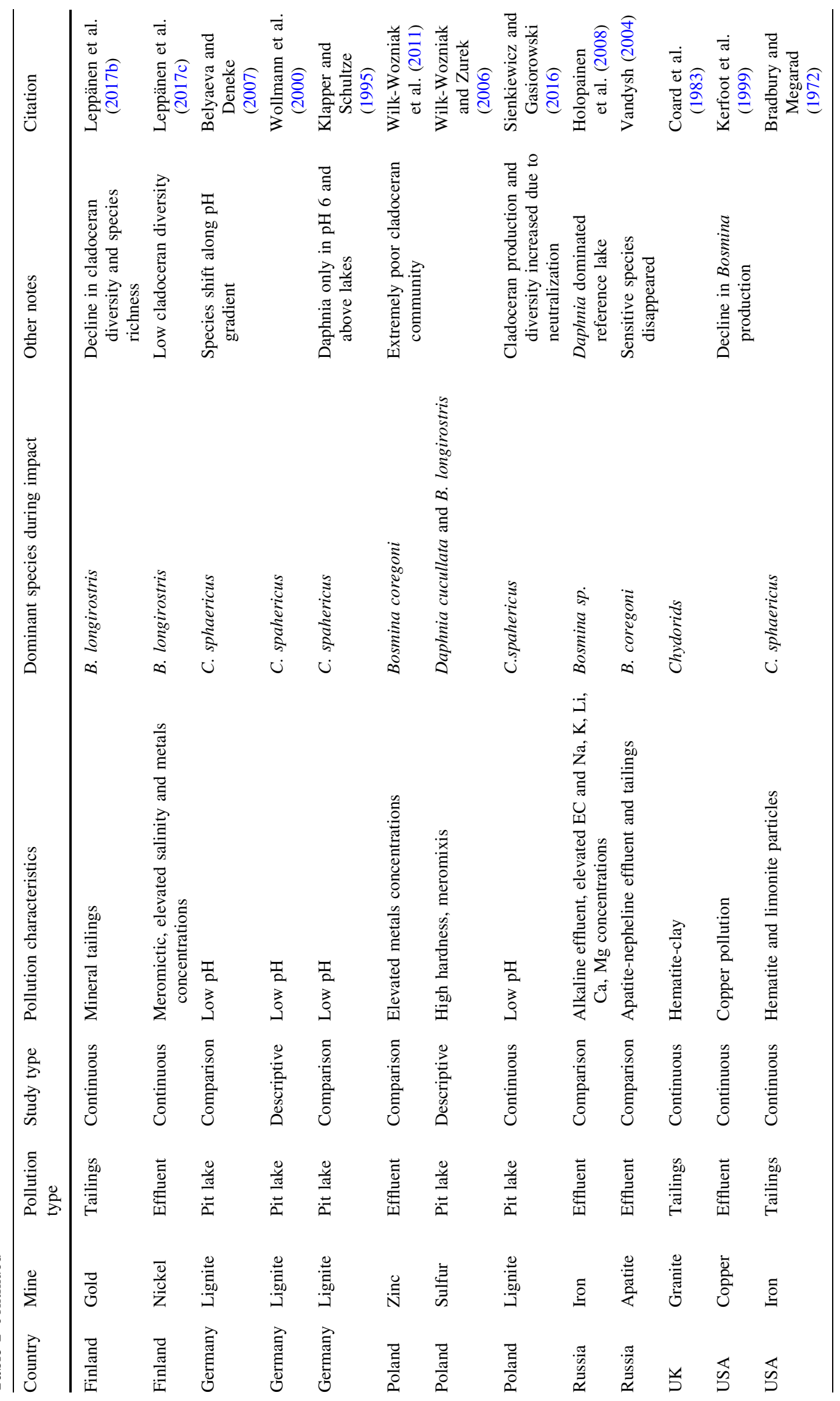




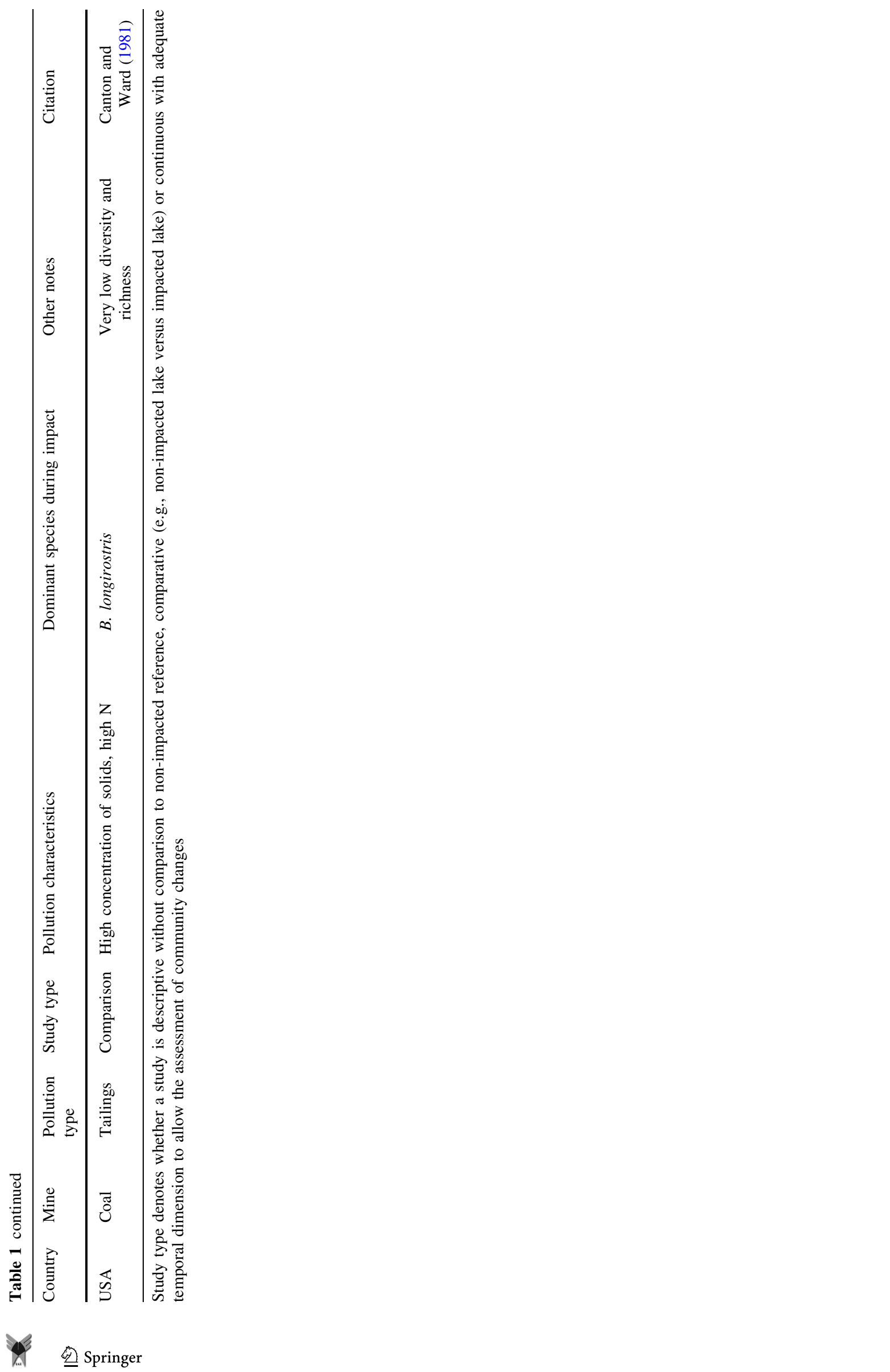


the central question in every bioindicator application (Markert et al. 2003) but due to the central location in food webs, the cladoceran community has the potential to reflect the surrounding environment in great detail.

The suggested endpoints for community level bioindicator studies are food web structure shifts or changes in species diversity (Harwell et al. 1987). With cladocera, the food web structure shifts (e.g., change in predator regime) are reflected in size structure in cladoceran community (Brooks and Dodson 1965) and to morphological changes among some species (Korosi et al. 2013). The increased dominance of the most tolerant taxa is reflected in diversity and richness indices due to the disappearance of rare or sensitive species from the community. Distinct changes in species composition (e.g., total loss of macrophyte associated species) may indicate the destruction of habitat (e.g., pronounced decline in macrophyte cover). However, it is challenging to determine whether a community has factually changed due to mine water input and what criteria should be used to detect the change. Namely, the natural variability of pre-disturbance community, disturbance impact and the post-disturbance community dynamics must be assessed. This can be achieved either by long term monitoring (e.g., Stow et al. 1998; Lindenmayer and Likens 2009), which are very rare, or paleolimnology (e.g., Smol 1992; Saros 2009). Luckily, historical cladoceran community can be reconstructed using paleolimnological methods (Korhola and Rautio 2001) and, in fact, the group is deemed a powerful tool for environmental reconstruction (Tolotti et al. 2016). Another highly important information, i.e., the exact point (or time) of community change, can be determined by applying statistical methods, such as broken-stick zonation (Bennett 1996), where significant changes in community are pinpointed or analysis of similarities, ANOSIM (Clarke 1993), which can be used as a test of significant difference between pre- and post-pollution communities. The perpetuity of the shift can be assessed by post-disturbance research (e.g., if the community recovers to its pre-disturbance form or is shifted to a new steady state). The information regarding predisturbance community (e.g., Battarbee 1999) and the possible recovery dynamics are of vital importance also in restoration and management purposes (European Union 2000). It must be noted that after the disturbance, the new community structure depends on source populations for recolonization and, thus, the niche availability (e.g., whether the most important niches are re-occupied or not) should be taken into account in addition to actual post-disturbance species composition.

Unfortunately, the reviewed literature does not allow the reliable identification of most vulnerable species, which could be used as early warning tools in mining pollution research. Partly, this is a result of incomplete reporting of cladoceran community. In many studies, only the dominant species were recorded and potentially very interesting data regarding most sensitive species were not available. In addition to community level considerations, widely distributed and highly resistant taxa C. sphaericus and Bosmina spp. may be successfully used as individual indicators. However, to further explore the potential of these two taxa as mine water indicators, more research (e.g., morphological changes due to pollution, population impacts, and life history changes) with Bosmina and Chydorus is needed. Luckily, some of this work has already been started (e.g., sedimentary toxicity test for C. spahericus has been developed; Dekker et al. 2005) but both of those groups are deemed challenging in terms of taxonomy (Belyaeva and Taylor 2009; Adamczuk 2016) which will hamper the applicability of Bosmina and Chydorus as global or regional indicators until the taxonomic issues are clarified. Moreover, as pointed out by Markert et al. (2003) bioindicator community or species level responses should be compared and "calibrated" to determine the indicator applicability of same species or species groups across regions and ecosystems. In addition to toxicological aspect, cladocerans can also be used in biomagnification studies (Stewart et al. 2008) and food web impact research (Draves and Fox 1998) in mine water studies. An interesting species, worth mentioning, is halophylic Daphnia exilis, which has been detected in reservoirs impacted by copper mine pollution in Chile (Heine-Fuster et al. 2010) and could thus be used as an indicator of saline mine drainage in the natural distribution area of this species.

\section{Further reading}

Besides the literature reviewed here, there are additional important resources for anyone working with cladocerans and mine pollution: The current role of cladocerans in ecotoxicological research in general has recently been reviewed by Sarma and Nandini (2006) and Suhett et al. (2015). In addition, the most important cladoceran species in toxicology research is Daphnia, which was extensively reviewed by Lampert (2011). Adamczuk (2016) reviewed Bosmina longirostris, one of the most important species when pollution impacts on cladoceran species composition are studied. Moreover, extensive data on mortality and reproduction in 
response to increasing concentrations of toxicants are available from databases, such as ECOTOX (2017). Detailed contribution on cladoceran physiology, where deeper look into the impact of xenobiotics is provided, was presented by Smirnov (2017). In addition to mine water impact, mining industry has also other effects on cladoceran communities. The lakes in the Sudbury mining region have been rigorously studied and the impacts of pollution originating from smelting and roasting processes on cladocerans have been assessed in many papers (e.g., Labaj et al. 2014, 2015; Thienpont et al. 2016). These studies would be a great benefit for anyone interested in cladocerans and mining pollution.

\section{Conclusion}

Clearly, there is a need to conduct further research in the field. The most interesting and necessary aspect is related to most sensitive species. Thus, it would be highly preferable if researchers published full species composition data even in cases, where only selected taxa are being studied in greater detail. Cladoceran potential as community level indicators is another issue which deserves more attention in research. For example, cladoceran community studies utilizing spatial and temporal aspects along pollution gradient could hold great potential in this sense. Finally, ecotoxicological research regarding the most tolerant taxa (Chydorus sphaericus and Bosmina longirostris) in natural setting is of utmost importance, but this should be preceded by clarification of the taxonomical issues of those species.

Acknowledgements This work was funded by Tellervo and Juuso Walden Foundation.

Open Access This article is distributed under the terms of the Creative Commons Attribution 4.0 International License (http:// creativecommons.org/licenses/by/4.0/), which permits unrestricted use, distribution, and reproduction in any medium, provided you give appropriate credit to the original author(s) and the source, provide a link to the Creative Commons license, and indicate if changes were made.

\section{References}

Adamczuk M (2016) Past, present, and future roles of small cladoceran Bosmina longirostris (O. F. Müller, 1785) in aquatic ecosystems. Hydrobiologia 767:1-11

Arruda JA, Marzolf GR, Faulk RT (1983) The role of suspended sediments in the nutrition of zooplankton in turbid reservoirs. Ecology 64:1225-1235

Battarbee RW (1999) The importance of paleolimnology to lake restoration. Hydrobiologia 395(396):149-159

Belyaeva M, Deneke R (2007) Colonization of acidic mining lakes: Chydorus sphaericus and other Cladocera within a dynamic horizontal pH gradient (pH $3-7$ ) in lake Senftenberger See (Germany). Hydrobiologia 594:97-108

Belyaeva M, Taylor DJ (2009) Cryptic species within the Chydorus sphaericus species complex (Crustacea: Cladocera) revealed by molecular markers and sexual stage morphology. Mol Phylogenet Evol 50:534-546

Bennett K (1996) Determination of the number of zones in a biostratigraphical sequence. New Phytol 132:155-170

Błędzki LA, Rybak JI (2016) Freshwater crustacean zooplankton of Europe. Springer, Swizerland

Bossuyt BTA, Janssen CR (2005) Copper toxicity to different field-collected cladoceran species: intra- and inter-species sensitivity. Environ Pollut 136:145-154

Bourg ACM, Loch JPG (1995) Mobilization of heavy metals as affected by $\mathrm{pH}$ and redox conditions. In: Salomons W, Stigliani WM (eds) Biogeodynamics of pollutants in soils and sediments. Environmental science. Springer, Berlin, pp 87-102

Bownik A (2017) Daphnia swimming behavior as a biomarker in toxicity assessment: a review. Sci Total Environ 601-602:194-205

Bozelli RL (1996) The influence of bauxite tailings on the cladoceran populations of Lake Batata, Amazonia, Brazil. Int Rev Hydrobiol 81:621-634

Bradbury JP, Megarad RO (1972) Stratigraphic record of pollution in Shagawa Lake, Northeastern Minnesota. Geol Soc Am Bull 83:2639-2648

Brooks JL, Dodson SI (1965) Predation, body size and composition of plankton. Science 150:28-35

Cain DJ, Luoma SN, Carter JL, Fend SV (1992) Aquatic insects as bioindicators of trace element contamination in cobble-bottom rivers and streams. Can J Fish Aquat Sci 49:2141-5154

Camargo JA, Alonso A, Salamanca A (2005) Nitrate toxicity to aquatic animals: a review with new data for freshwater invertebrates. Chemosphere 58:1255-1267

Canadian Government (2002) Metal mining effluent regulations. SOR/2002-222

Canton SP, Ward JV (1981) Benthos and zooplankton of coal strip mine ponds in the mountains of northwestern Colorado, U.S.A. Hydrobiologia 85:23-31

Chen G, Shi H, Tao J, Chen L, Liu Y, Lei G, Liu X, Smol P (2016) Industrial arsenic contamination causes catastrophic changes in freshwater ecosystem. Sci Rep 5:17419. https://doi.org/10.1038/srep17419 
Clarke KR (1993) Non-parametric multivariate analysis of changes in community structure. Aust J Ecol 18:117-143

Coard MA, Cousen SM, Cuttler AH, Dean HJ, Dearing JA, Eglinton TI, Greaves AM, Lacey KP, O'Sullivan PE, Pickering DA, Rhead MM, Rodwell JK, Simola H (1983) Paleolimnological studies of annually-laminated sediments in Loe Pool, Cornwall, U.K. Hydrobiologia 103:185-191

Cuker BE (1987) Field experiment on the influences of suspended clay and P on the plankton of a small lake. Limnol Oceanogr 32:840-847

Dekker T, Greve GD, Ter Laak TL, Boivin ME, Veuger B, Gortzak G, Dumfries S, Lücker SMG, Kraak MHS, Admiraal W, van der Geest HG (2005) Development and application of a sediment toxicity test using the benthic cladoceran Chydorus sphaericus. Environ Pollut 140:231-238

Doig LE, Schiffer ST, Liber K (2015) Reconstructing the ecological impacts of eight decades of mining, metallurgical, and municipal activities on a small boreal lake in Norther Canada. Integr Environ Assess Manag 11:490-501

Draves JF, Fox MC (1998) Effects of a mine tailings spill on feeding and metal concentrations in juvenile perch (Perca fluviatilis). Environ Toxicol Chem 17:1626-1632

Dumont HJ (1989) The non-marine Cladocera in Belgium. In: Wouters K, Baert, L (eds) Proceedings of the symposium "Invertebrates of Belgium". Brussel, 25-26 November 1988, pp 137-142

ECOTOX (2017) The ecotoxicology database. https://cfpub.epa.gov/ecotox/ecotox_home.cfm. Accessed 17 May 2017

El-Bassat RA, Taylor WD (2007) The zooplankton community of Lake Abo Zaabal, a newly-formed mining lake in Cairo, Egypt. Afr J Aquat Sci 32:185-192

Elphick JR, Davies M, Gilron G, Canaria EC, Lo B, Bailey HC (2011) An aquatic toxicological evaluation of sulfate: the case for considering hardness as a modifying factor in setting water quality guidelines. Environ Toxicol Chem 30:247-257

European Union (2000) Directive 2000/60/EC of the European Parliament and of the Council of 23 October 2000 establishing a framework for community action in the field of water policy. Off J Eur Communities L327:1-72

Ferrari CR, Wisniewski MJ, Roque CV, Ronque LB, Campos MB, Rodgher S, Nascimento MRL, de Azevedo H (2009) Preliminary assessment of the zooplankton community composition in a region under the influence of a uranium mine (Caldas, southeastern Brazil). International Nuclear Atlantic Conference-INAC 2009. Rio de Janeiro, RJ, Brazil, September 27 to October 2, 2009 (ISBN 978-85-99141-03-8)

Ferrari CR, de Azevedo H, Wisniewski MJS, Roddgher S, Roque CV, Nascimento MRL (2015) An overview of an acidic uranium mine pit lake (Caldas, Brazil): composition of the zooplankton community and limnochemical aspects. Mine Water Environ 34:343-351

Ferrari CR, de Azevedo H, Nascimento F, Rodgher S, Almeida T, Bruschi AL, Nascimento MRL, Bonifacio RL (2017) Effects of the discharge of uranium mining effluents on the water quality of the reservoir: an integrative chemical and ecotoxicological assessment. Sci Rep 7:13919. https://doi.org/10.1038/s41598-017-14100-w

Garrido AV, Bozelli RL, De Esteves FA, Alves LS (2003) Long-term patterns of the planktonic cladoceran community of Batata Lake, Amazonia, Brazil. Acta Limnol Bras 15:41-53

Griffiths K, Thienpont J, Jeziorski A, Smol JP (2018) The impact of Ca-rich diamond mining effluent on downstream communities in softwater lakes of the Northwest Territories, Canada. Can J Fish Aquat Sci. https://doi.org/10.1139/cjfas-2017-0469

Hart RC (1987) Population dynamics and production of five crustacean zooplankton in a subtropical reservoir during years of contrasting turbidity. Freshw Biol 18:287-318

Harwell MA, Harwell CC, Weinstein DA, Kelly JR (1987) Anthropogenic stresses on ecosystems: issues and indicators of response and recovery. ERC-153. Ecosystems Research Center, Ithaca

Heine-Fuster I, Vega-Retter C, Sabat P, Ramos-Jiliberto R (2010) Osmoregulatory and demographic responses to salinity of the exotic cladoceran Daphnia exilis. J Plankton Res 32:1405-1411

Holopainen IJ, Holopainen A-L, Huitu E, Rahkola-Sorsa M, Zingel P (2008) The pelagic food web in forest lakes affected by alkaline mining waste in NW Russia. Est J Ecol 57:214-228

Hudson-Edwards KA, Dold B (2015) Mine waste characterization, management and remediation. Minerals 5:82-85

Jäger IS, Hölker F, Flöder S, Walz N (2011) Impact of Chaoborus flavicans on the zooplankton in a mesotrophic lake-a three year study. Internat Rev Hydrobiol 96:191-208

Jeppesen E, Nõges P, Davidson T, Haberman J, Nõges T, Blank K, Lauridsen T, Søndergaard M, Sayer C, Laugaste R, Johansson L, Bjerring R, Amsinck S (2011) Zooplankton as indicators in lakes: a scientific_-based plea for including zooplankton in the ecological quality assessment of lakes according to the European Water Framework Directive (WFD). Hydrobiologia 676:279-297

Kerfoot WC, Robbins JA, Weider LJ (1999) A new approach to historical reconstruction: combining descriptive and experimental paleolimnology. Limnol Oceanogr 44:1232-1247

Kirk KL, Gilbert JJ (1990) Suspended clay and the population dynamics of planktonic rotifers and cladocerans. Ecology 71:1741-1755

Klapper H, Schultze M (1995) Geogenically acidified mining lakes-living conditions and possibilities of restoration. Int Rev Hydrobiol 80:639-653

Koivisto S, Ketola M (1995) Effects of copper on life-history traits of Daphnia pulex and Bosmina longirostris. Aquat Toxicol 32:255-269

Koivisto S, Ketola M, Walls M (1992) Comparison of 5 cladoceran species in short- and long-term copper exposure. Hydrobiologia 248:125-136

Korhola A, Rautio M (2001) Cladocera and other Branchiopod crustaceans. In: Smol JP, Birks HJB, Last WM (eds) Tracking environmental change using lake sediments, vol 4. Zoological indicators. Kluwer Academic Publishers, Dordrecht, pp 5-41

Korosi JB, Kurek J, Smol JP (2013) A review on utilizing Bosmina size structure archieved in lake sediments to infer historic shifts in predation regimes. J Plankton Res 53:444-460 
Kozlova T, Wood CM, McGeer JC (2008) The effect of water chemistry on the acute toxicity of nickel to cladoceran Daphnia pulex and the development of a biotic ligand model. Aquat Toxicol 91:221-228

Kurek J, Kirk JL, Muir DCG, Wang X, Evans MS, Smol JP (2012) Legacy of a half century of Athabasca oil and development recorded by lake ecosystems. Proc Natl Acad Sci USA 110:1761-1766

Labaj AL, Jeziorski A, Kurek J, Smol JP (2014) Long-term trends in Cladoceran assemblages related to acidification and subsequent liming of Middle Lake (Sudbury Canada). Water Air Soil Pollut 225:1868. https://doi.org/10.1007/s11270-014$1868-2$

Labaj AL, Kurek J, Jeziorski A, Smol JP (2015) Elevated metal concentrations inhibit biological recovery of Cladocera in previously acidified boreal lakes. Freshw Biol 60:347-359

Lampert W (2011) Daphnia: development of a model organism in ecology and evolution. Excellence in ecology, book 21. International Ecology Institute, Oldendorf

Leppänen J, Siitonen S, Weckström J (2016) The stability of cladoceran communities in sub-arctic NW Finnish Lapland lakes. Polar Biol 40:2211-2223

Leppänen J, Weckström J, Korhola A (2017a) Paleolimnological fingerprinting of the impact of acid mine drainage after 50 years of chronic pollution in a southern Finnish lake. Water Soil Air Pollut 228:227. https://doi.org/10.1007/s11270-017-3417-2

Leppänen J, Weckström J, Korhola A (2017b) Mining pollution triggered a regime shift in cladoceran community of Lake Kirkkojärvi. J Paleolimnol, S Finland. https://doi.org/10.1007/s10933-018-0030-3

Leppänen J, Weckström J, Korhola A (2017c) Multiple mining impacts induce widespread changes in ecosystem dynamics in a boreal lake. Sci Rep 7:10581. https://doi.org/10.1038/s41598-017-11421-8

Lindenmayer DB, Likens GE (2009) Adaptive monitoring: a new paradigm for long-term research and monitoring. Trends Ecol Evol 24:482-486

Lopes I, Goncalves F, Soares AMVM, Ribeiro R (1999) Discriminating the ecotoxicity due to metals and to low pH in acid mine drainage. Ecotox Environ Safe 44:207-214

Lundstedt L, Brett MT (1991) Differential growth rates of three cladoceran species in response to mono- and mixed-algal cultures. Limnol Oceanogr 36:159-165

Maia-Barbosa PM, Bozelli RR (2005) Length-weight relationships for five cladoceran species in an Amazonian lake. Braz Arch Biol Technol 48:303-308

Markert BA, Breure AM, Zechmeister HG (2003) Definitions, strategies and principles for bioindication/biomonitoring. In: Markert BA, Breure AM, Zechmeister HG (eds) Bioindicators \& biomonitors. Principles, concepts and applications. Trace metals and other contaminants in the environment 6. Elsevier, Kidlington, pp 3-39

McCabe GD, O'Brien WJ (1983) The effects of suspended silt on feeding and reproduction of Daphnia pulex. Am Midl Nat 110:324-337

Melville GE (1995) Changes in pelagic crustacean zooplankton of high-boreal Island Lake, Saskatchewan, associated with uranium mining. Environ Monit Assess 34:45-58

Miller GC, Lyons WB, Davis A (1996) Understanding the water quality of pit lakes. Environ Sci Technol 30:118A-123A

Molenda T (2014) Impact of saline mine water: development of a meromictic reservoir in Poland. Mine Water Environ 33:327-334

Moreira FWA, Leite MGP, Fujaco MAG, Mendoca FPC, Campos LP, Eskinazi-Sankt'Anna EM (2016) Assessing the impacts of mining activities on zooplankton functional diversity. Acta Limnol Bras. https://doi.org/10.1590/S2179-975X0816

Moser M, Weisse T (2011) The most acidified Austrian lake in comparison to a neutralized mining lake. Limnologica 41:303-315

Nevalainen L, Luoto TP (2013) Limnological deterioration forces community and phenotypic changes in Cladocera: tracking eutrophication of Mallusjärvi, a lake in southern Finland. Boreal Env Res 18:209-222

Nixdorf B, Mischke U, Leßmann D (1998) Chrysophytes and chlamydomonads: pioneer colonists in extremely acidic mining lakes $(\mathrm{pH}<3$ ) in Lusatia (Germany). Hydrobiologia 369(370):315-327

Niyogi S, Wood CM (2004) Biotic ligand model, a flexible tool for developing site-specific water quality guidelines for metals. Environ Sci Technol 38:6177-6192

Nordstrom DK (2011) Mine waters: acidic to circumneutral. Elements 7:393-398

Persoone G, Baudo R, Cotman M, Blaise C, Thompson KCL, Moreira-Santos M, Vollat B, Törökne A, Han T (2009) Review on the acute Daphnia magna toxicity test-evaluation of the sensitivity and the precision of assays performed with organisms from laboratory cultures or hatched from dormant eggs. Knowl Manag Aquat Ecosyst 393:1. https://doi.org/10.1051/kmae/ 2009012

Reichl C, Schatz M, Zsak G (2016) World mining data. Volume 31. Minerals Production. International organizing committee for the world mining congresses. Federal Ministry of Science, Research and Economy, Vienna

Rogalski MA (2015) Tainted resurrection: metal pollution is linked with reduced hatching and high juvenile mortality in Daphnia egg banks. Ecology 96:1166-1173

Rumes B, Eggermont H, Verschuren D (2011) Distribution and faunal richness of Cladocera in western Uganda crater lakes. Hydrobiologia 676:39. https://doi.org/10.1007/s10750-011-0829-7

Salmelin J, Leppänen MT, Karjalainen AK, Vuori K-M, Gerhardt A, Hämäläinen H (2017) Assessing ecotoxicology of biomining effluents in stream ecosystems by in situ invertebrate bioassays: a case study in Talvivaara, Finland. Environ Toxicol Chem 36:147-155

Sarma SSS, Nandini S (2006) Review of recent ecotoxicological studies on cladocerans. J Environ Sci Health B 41:1417-1430

Saros JE (2009) Integrating neo- and paleolimnological approaches to refine interpretations of environmental change. J Paleolimnol 41:243-252

Schultze M, Pokrandt K-H, Hille W (2010) Pit lakes of the Central German lignite mining district: creation, morphometry and water quality aspects. Limnologica 40:148-155 
Schultze M, Boehrer B, Wendt-Potthoff K, Sánchez-España J, Castendyk D (2017) Meromictic pit lakes: case studies from Spain, Germany and Canada and general aspects of management and modelling. In: Gulati RD, Zadereev ES, Degermendzhi AG (eds) Ecology of meromictic lakes. Springer, Berlin, pp 235-275

Sienkiewicz E, Gąsiorowski M (2016) The evolution of a mining lake-From acidity to natural neutralization. Sci Total Environ 557-558:343-354

Smirnov N (2017) Physiology of the Cladocera. Elsevier Academic Press, London

Smol JP (1992) Paleolimnology: an important tool for effective ecosystem management. J Aquat Ecosyst Health 1:49-58

Sofyan A, Shaw JR, Birge WJ (2009) Metal trophic transfer from algae to cladocerans and the relative importance of dietary metal exposure. Environ Toxicol Chem 25:1034-1041

Stankovic I, Ternjej I (2009) New data on Croatian crustacean plankton fauna (Copepoda \& Cladocera) in Cingi-Lingi Lake. Nat Croat 18:181-184

Stankovic I, Ternjej I, Mihaljevic Z, Furac L, Kerovec M (2011) Crustacean plankton community (Crustacea: Copepoda and Cladocera) in gypsum karst lakes and their relation to abiotic parameters. Hydrobiologia 666:145-153

Sterner RW (2009) Role of zooplankton in aquatic ecosystems. In: Likens GE (ed) Encyclopedia of inland waters. Academic Press, Oxford, pp 678-688

Stewart RA, Saiki MK, Kuwabara JS, Alpers CN, Marvin-DiPasquale M, Krabbenhoft DP (2008) Influence of plankton mercury dynamics and trophic pathways on mercury concentrations of top predator fish of a mining-impacted reservoir. Can J Fish Aquat Sci 65:2351-2366

Stow CA, Carpenter SR, Webster KE, Frost TM (1998) Long-term environmental monitoring: some perspectives from lakes. Ecol Appl 8:269-276

Suhett AL, Santangelo JM, Bozelli RL, Steinberg CEW, Farjalla VF (2015) An overview of the contribution of studies with cladocerans to environmental stress research. Acta Limnol Bras 27:145-159

Thienpont JR, Korosi JB, Hargan KE, Williams T, Eickmeyer DC, Kimpe LE, Palmer MJ, Smol JP, Blais JM (2016) Multitrophic level response to extreme metal contamination from gold mining in a subarctic lake. Proc R Soc Lond B Biol Sci 283:1836. https://doi.org/10.1098/rspb.2016.1125

Tolotti M, Milan M, Szeroczynska K (2016) Subfossil Cladocera as a powerful tool for paleoecological reconstructions. Adv Oceanogr Limnol. https://doi.org/10.4081/aiol.2016.6467

Tõnno I, Agasild H, Kõiv T, Freiberg R, Nõges P, Nõges T (2016) Algal diet of small-bodied crustacean zooplankton in a cyanobacteria-dominated eutrophic Lake. PLoS ONE 11(4):e0154526. https://doi.org/10.1371/journal.pone.0154526

Vad CF, Horvàth Z, Kiss KT, Àcs È (2012) Microcrustacean (cladoceran, copepod) communities in artificial lakes in the region of the north hungarian mountains, with special reference to the adventive species. Acta Zool Acad Sci Hung 58:47-61

Valente T, Gomes CL (2007) The role of two acidophilic algae as ecological indicators of acid mine drainage sites. J Iber Geol 33:283-294

Van Dam RA, Harford AJ, Lunn SA, Gagnon MM (2014) Identifying the cause of toxicity of a saline mine water. PLoS ONE 9(9):e106857. https://doi.org/10.1371/journal.pone.0106857

Vandysh OI (2004) Zooplankton as an indicator of the state of lake ecosystems polluted with mining wastewater in the Kola Peninsula. Russ J Ecol 35:134-140

Vink J, Verschoor A (2010) Biotic ligand models: availability, performance and applicability for water quality assessment. Deltares, Netherlands

Von Der Ohe PC, Liess M (2004) Relative sensitivity distribution of aquatic invertebrates to organic and metal compounds. Environ Toxicol 23:150-156

Wolkersdorfer C, Bowell R (2005) Contemporary Reviews of Mine Water Studies in Europe, Part 3. Mine Water Environ 24:58-76. https://doi.org/10.1007/s10230-005-0074-2

Watling HR (2015) Review of biohydrometallurgical metals extraction from polymetallic mineral resources. Minerals 5:1-60

Wilk-Woźniak E, Zurek R (2006) Phytoplankton and its relationships with chemical parameters and zooplankton in the meromictic Piasecno reservoir, South Poland. Aquat Ecol 40:165-176

Wilk-Woźniak E, Pociecha A, Ciszewski D, Aleksander-Kwaterczak U, Walusiak E (2011) Phyto- and zooplankton in fishponds contaminated with heavy metal runoff from a lead-zinc mine. Oceanol Hydrobiol Stud 40:77-85

Winegardner AK, Salter N, Aebischer S, Pienitz R, Derry AM, Wing B, Beisner BE, Gregory-Eaves I (2017) Cladoceran diversity dynamics in lakes from a northern mining region: responses to multiple stressors characterized by alpha and beta diversity. Can J Fish Aquat Sci 74:1654-1667

Wollmann K, Deneke R, Nixdorf B, Packroff G (2000) Dynamics of planktonic food webs in three mining lakes across a pH gradient (pH 2-4). Hydrobiologia 433:3-14

Yount JD, Niemi GJ (1990) Recovery of lotic communities and ecosystems from disturbance-a narrative review of case studies. Environ Manage 14:547-569

Zawisza E, Zawiska I, Correa-Metrio A (2016) Cladocera community composition as a function of physicochemical and morphological parameters of dystrophic lakes in NE Poland. Wetlands 36:1131-1142

Zhou Q, Zhang J, Fu J, Shi J, Jiang G (2008) Biomonitoring: an appealing tool for assessment of metal pollution in the aquatic ecosystem. Anal Chim Acta 606:135-150

\section{Publisher's Note}

Springer Nature remains neutral with regard to jurisdictional claims in published maps and institutional affiliations. 